\title{
O skutkach nadmiernej eksploracji stylistyki - „Zerwany kłos”
}

\begin{abstract}
Streszczenie
Celem analizy Zerwanego kłosa jest zbadanie jego wartości. Badanie to wyróżnia dwa możliwe sposoby oceny filmu. Pierwszy sposób dotyczy jakości filmu jako wyrazu działania estetycznego. Wiąże się ono z traktowaniem filmu jako sztuki. W tym zakresie decydujące znaczenie mają kwestie formalne i umiejętność wykorzystania przez twórców stylistyki filmowej oraz skonstruowania spójnej opowieści. Drugie sposób wiąże się z gatunkowym przyporządkowaniem tego filmu. W kinie religijnym (hagiografia) najważniejsza może być przekazywana idea, choć jednocześnie można zachować zasady konstrukcji znaczeń w filmie. Ogólną ramą metodologiczną są trzy aspekty dyskursu van Dijka. Na poziomie szczegółowym wykorzystane jest klasyczne podejście do języka i stylistyki filmu, podejście neoformalistów amerykańskich oraz koncepcji stylu zerowego. Wnioski z przeprowadzonej analizy wskazują na niską wartość filmu z punktu widzenia sztuki filmowej i wysoką wartość w zakresie realizacji celów gatunkowych (tu: ideologicznych). Negatywna ocena wynika z nadmiaru wykorzystania przez młodych twórców możliwości technicznych i warsztatowego (zbyt licznego) stosowania formalnych rozwiązań możliwych w ramach stylistyki filmowej. Pozytywne wniosek w zakresie realizacji zakładanego celu wiąże się ze skutecznością dotarcia do zdefiniowanego przez producenta odbiorcy, tak pod względem ich liczby, jak i w zakresie przekazanych idei, zgodnych z ich
\end{abstract}

1 Marcin Szewczyk, Wydział Administracji i Nauk Społecznych, Wyższa Szkoła Informatyki i Zarządzania z siedzibą w Rzeszowie, Polska, e-mail: mszewczyk@wsiz.rzeszow.pl, ORCID ID: https://orcid.org/0000-0003-3699-5559. 
światopoglądem. Pomimo deklaracji twórców o rzetelnym odtworzeniu rzeczywistości życia błogosławionej Karoliny Kózkówny, konieczność przekazu zaplanowanych koncepcji wprowadziła kreacyjne wątki treściowe, wpływając na realność przedstawianej historii i wprowadzając problemy ze spójną i sprawną rekonstrukcja fabuły. Rozszerzyło to zakres promowanych wartości poza te związane z życiem głównej bohaterki filmu, odnosząc je do współczesnego polskiego dyskursu politycznego i społecznego.

\title{
Słowa kluczowe:
}

komunikacja społeczna, media, analiza dyskursu, film, KAD, kino religijne, stylistyka filmu, język filmu

\begin{abstract}
The aim of the Zerwany kłos analysis is to examine its value. This study distinguishes two possible ways to evaluate the film. The first method concerns the quality of the film as an expression of the aesthetic effect. It involves treating the film as an art. In this respect, formal issues and the ability to use film stylistics and construct a coherent story are decisive. The second way is related to the genre of this movie. In religious cinema (hagiography) the most important thing can be the idea conveyed, although at the same time the principles of constructing meanings in the film can be preserved. The overall methodological framework is three aspects of Van Dijk's discourse. At the detailed level, the classic approach to language and stylistics of the film is used, the American neoformalist approach and the zero-style concept. The conclusions from the conducted analysis point to the low value of film from the point of view of film art and high value in the implementation of genre objectives (here: ideological). The negative assessment results from the excess of young creators' use of technical and workshop possibilities (too many) of applying formal solutions possible within the film style. A positive conclusion in the scope of accomplishing the assumed goal is related to the effectiveness of reaching the recipient defined by the producer, both in terms of their number and in terms of the ideas conveyed, consistent with their worldview. Despite the creators' declarations about a reliable reconstruction of the reality of Blessed Karolina Kózkówna's life, the necessity of transmitting planned concepts introduced creative content threads, influencing the reality of the presented story and introducing problems with a coherent and efficient reconstruction of the plot. This widened the range of promoted values beyond those related to the life of the main character of the film, referring them to the contemporary Polish political and social discourse.
\end{abstract}




\section{Keywords:}

social communication, media, discourse analisys, film, CDA, religious cinema, film style, film language

\section{TEMAT - TEZA - ZAŁOŻENIA - METODA}

Zerwany kłos jest pierwszym filmem wyprodukowanym przez Fundację Lux Veritatis (TV Trwam wytwórnia filmowa). Już samo to skłania do uważnego przyjrzenia się temu, jak został zrealizowany, o czym opowiada i jak ta historia została z filmowego punktu widzenia przedstawiona. Dodatkowo jest on firmowany przez Wyższą Szkołę Kultury Społecznej i Medialnej z Torunia, a w materiałach informacyjnych dla dziennikarzy zamieszczonych na stronie tej produkcji jest podkreślone że: „Średnia wieku członków całego zespołu filmowego wynosi około 27 lat. Żaden z nich nie studiował w żadnej szkole filmowej” (Materiały, 2017, s. 15), a twórcy w tyłówce filmu dziękują Zarządowi Lux Veritatis oraz Zarządowi Fundacji Nasza Przyszłość (która częściowo finansowała film) „za zaufanie okazane młodym artystom”.

Pomimo licznych recenzji i opisów tego filmu trudno jest na ich podstawie stwierdzić, czy jest to kino wartościowe. Są one bowiem skrajnie odmienne, a podział przebiega zgodnie z linią podziału wytyczoną przez sympatię lub niechęć do producenta, a także religijność widza (Salwowski, 2017; Tatarska, 2017).

Podejmując się nierecenzyjnej oceny tego filmu, konieczne jest podążenie dwiema ścieżkami. Pierwsza wiąże się ściśle z jakością tego obrazu w zakresie sposobu wykorzystania możliwości, jakie daje materia filmowa, druga natomiast dotyczy konsekwencji jego przyporządkowania gatunkowego. Do drugiej odwołuje się teza, zgodnie z którą z jednej strony film ten w zakresie sztuki filmowej (i koncentracji na równowadze, harmonii i zrównoważonym użyciu ruchomych obrazowych oraz dźwiękowych środków ekspresji) nie ma żadnej wartości, z drugiej strony ze względu na realizowane za jego pośrednictwem pozafilmowe cele społeczne (w tym religijne) jest bardzo wartościowy. Na tej podstawie został sformułowany tytuł tej analizy, mówiącej o skutkach (dwuwartościowych) nadmiernego (błędnego) wykorzystania stylistyki filmowej (i gatunkowej).

Przyjęte założenia wyjściowe w znacznym stopniu determinuje wybór metodologii badawczych. Ze względu na kontekst powstania filmu użytecznym narzędziem o charakterze ogólnej ramy analitycznej jest odwołanie się do trzech aspektów dyskursu Teuna van Dijka (1997). Analiza języka w użyciu jest realizowana przez badanie filmowych środków wyrazu i stylistyki filmowej, idea (jawna 
i ukryta) wiąże się z określeniem wartości filmu ze względu na przekazywane treści i sposób ich prezentacji, natomiast interakcja społeczna odzwierciedla się w społecznych aspektach jego odbioru. Na płaszczyźnie analizy dzieła filmowego badanie przyjmuje ogólną metodę warsztatowo-konstrukcyjną (jej pionierem w Polsce był Bolesław W. Lewicki, a następnie początkowo Alicja Helman) oraz formalno-rekonstrukcyjną. Narzędziowo będą temu służyły elementy klasycznego podejścia do języka i stylistyki filmu (Płażewski, 1961), neoformalnej koncepcji narracji parametrycznej (Thompson, Bordwell, 1976; Bordwell, 1985) oraz w mniejszym stopniu koncepcji przezroczystości formy filmowej (stylu zerowego (Przylipiak, 1994)). Ten niewyczerpujący wszystkich możliwości analitycznych i wykorzystany w różnym stopniu zbiór koncepcji pozwala odnieść się do filmowości analizowanego obrazu i dokonać jego oceny z punktu widzenia sztuki filmowej. Analiza ta nie dotyczy wszystkich elementów i składników języka filmu, nie koncentruje się na opisie pełnej treści i dotyczy przede wszystkim - w ramach wskazanych metod badawczych - badania stylistyki filmu oraz związanej z jego powstaniem i udostępnieniem - sfery społecznej.

Istotnym założeniem analizy jest uznanie, że dzieło filmowe jest w pełni intencjonalne, a jego kształt uzależniony jest od świadomego twórcy, który konstruuje rzeczywistość pełną, przy wykorzystaniu takich środków wyrazu, które najlepiej (celowo i dążąc do przezroczystości formy) pozwolą sformułować wypowiedź filmową. Pomimo tego, że w tym przypadku można mówić o nadawcy zbiorowym (lub instytucjonalnym), to za ostateczny kształt rozwiązań i decyzji twórczych odpowiedzialny jest reżyser, wspierany przez zespół twórczy, realizujący zamierzenia producenta.

\section{WĄTKI FABULARNE}

Film przez producenta jest określany jako hagiografia (i dramat historyczny), czyli opis życia osoby świętej. Nie musi on obejmować całego życiorysu postaci, może także przywoływać cudowne lub szczególnie ważne z punktu widzenia świętości wydarzenia z jej życia. Jednak nawet zgodnie z takim kluczem jedynie w nikłym stopniu uzasadnione jest rozbudowanie fabuły filmu w taki sposób, że składają się na nią dwa wątki zależne. Pierwszym jest przedstawianie sposobu życia i męczeńskiej śmierci błogosławionej Karoliny Kózkówny, drugim natomiast historia zgwałconej Teresy, która pomimo wszystkich okoliczności decyduje się na urodzenie dziecka. Szczęśliwie dla konstrukcji filmu i całego sjużetu - historia Teresy nie jest opowieścią prowadzoną w innym miejscu i w innym czasie, lecz 
przeplata się ściśle z losami Karoliny Kózkówny. Ten wątek zależny wypełnia znaczną część filmu i wprowadza dodatkową tezę. Tezę, która nie w pełni, nie wprost i nie bezpośrednio wiąże się z charakterystycznymi cechami duchowości błogosławionej (ta kwestia jest szerzej omówiona w części dotyczącej nadmiarowości). Szczegółowo przedstawiona w sjużecie historia Teresy pełni kilka dodatkowych ról na poziomie konstrukcji filmu i jego treści.

Film został podzielony na cztery rozdziały, z których jeden w całości został poświęcona Teresie. Ponadto wątek Teresy pojawia się także w innych częściach, to z nią związana jest jedna z klamer kompozycyjnych filmu. Każdy z rozdziałów jest poprzedzony kadrem zawierającym przemalowane ujęcie oraz tytuł (ryc. 1).

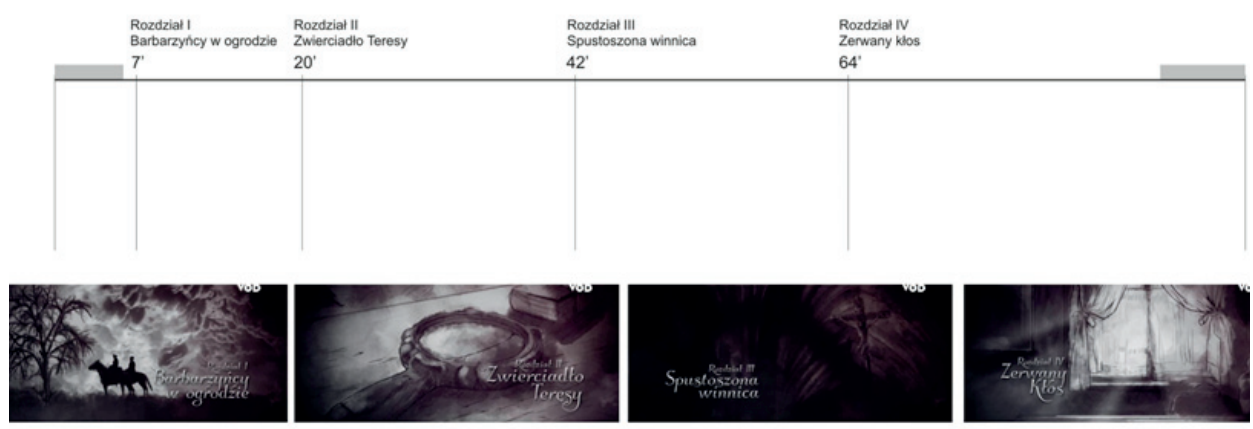

Ryc. 1

\section{KLAMRY - NARRATORZY - NAPISY}

Te trzy grupy zabiegów typowych dla stylistyki filmowej - przy zrównoważonym stosowaniu - dobrze wpływają na odbiór filmu. Nie szkodzą one ani konstrukcji świata przedstawionego, często są wręcz oczekiwane przez widza, i pozwalają lepiej rekonstruować fabułę.

Pierwszą pełnoprawną, choć nie diegetyczną, klamrą kompozycyjną jest odwołanie do Jana Pawła II. Na początku filmu (przed czołówką) jest to plansza z cytatem, dodatkowo odczytanym przez narratora, na końcu filmu (w ramach tyłówki) jest to scena, w której bohaterka filmu, stojąc na współczesnej ulicy Krakowa patrzy w okno z portretem papieża i pojawia się napis dedykujący mu film (ryc. 2 i 3).

Druga klamra kompozycyjna - także zachowująca w pełni charakter tego zabiegu - może być jednocześnie potraktowana jako leitmotiv. Jest to ujęcie odsyłające do rzeczywistości duchowej, a przez symboliczną doskonałość i czystość świata w niej przedstawionego - do miejsca przebywania Karoliny Kózkówny po 


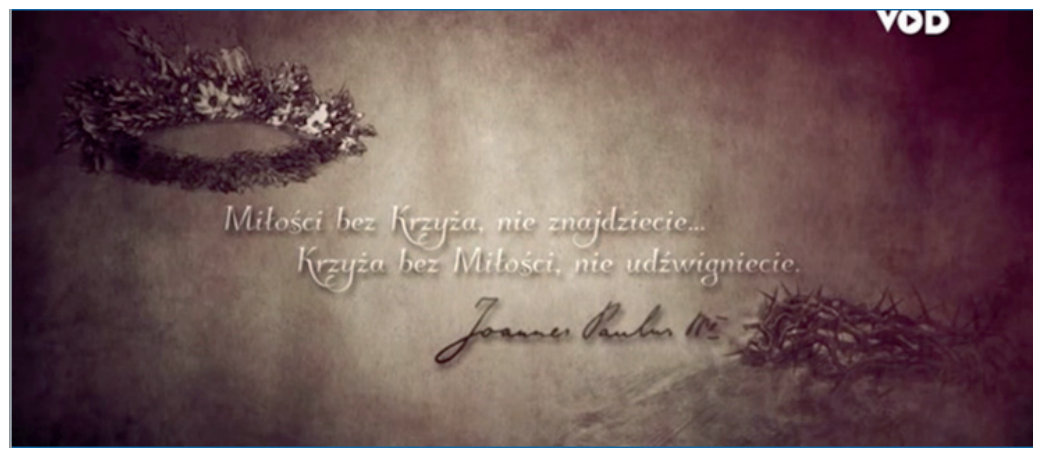

\section{Ryc. 2}

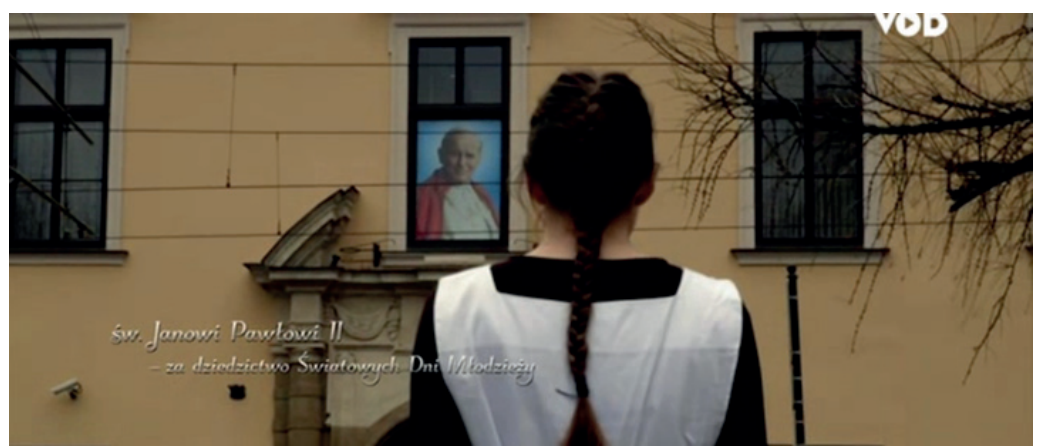

Ryc. 3

śmierci. Podkreśla to przy scenie zamykającej klamrę niediegetyczny komentarz wszechwiedzącego narratora współczesnego. Ponieważ ten wizualny motyw pojawia się dodatkowo także kilka minut po jego wprowadzeniu na początku filmu (w czołówce) i kilka minut przed zamknięciem klamry (przed tyłówką) na końcu filmu, a także ze względu na wykorzystanie go na głównym plakacie promującym film, można go uznać jednocześnie za motyw przewodni filmu (ryc. 4).

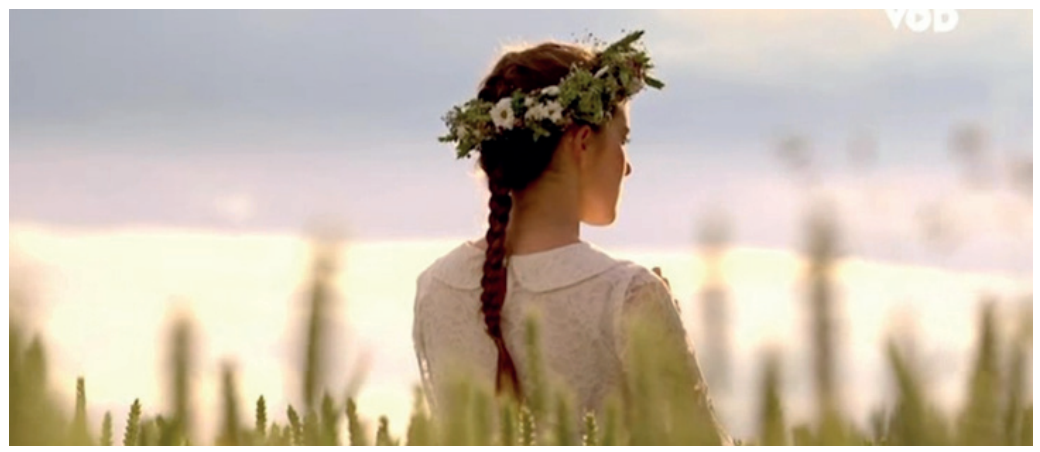

Ryc. 4 
Trzecia klamra jest osadzona w fabule, zaczyna się w czołówce, jednak scena zamykająca zastała umieszczona aż pięć minut przed końcem sjużetu. Przedstawia przyszłość - szczęśliwą Teresę w domu z dzieckiem, z dobiegającymi z offu jej słowami odwołującymi się do Boga, które odnosząc się do treści filmu, mogą zostać potraktowane jako morał, wyjaśnienie, podsumowanie i hagiograficzna interpretacja przedstawianych wydarzeń. W jakimś stopniu może to sugerować, co byłoby częściowo uzasadnione znaczeniem i częstotliwością pojawiania się jej wątku w filmie, że cała opowieść, to historia Karoliny Kózkówny opowiedziana z punktu widzenia Teresy. Jednak tylko częściowo. Nie znajduje to bowiem pełnego uzasadnienia w ukazywaniu wydarzeń, w których nie tylko nie mogła brać udziału, ale i o których nie mogła wiedzieć. Ponadto analogiczne ujęcia (bez komentarza i w skrócie) są wykorzystane na początku drugiego rozdziału filmu, sugerując, że przynajmniej ta część jest oparta na jej wspomnieniach. Choć i tu można postawić podobne zarzuty dotyczące jej niewiedzy o części przedstawionych w sjużecie wydarzeń.

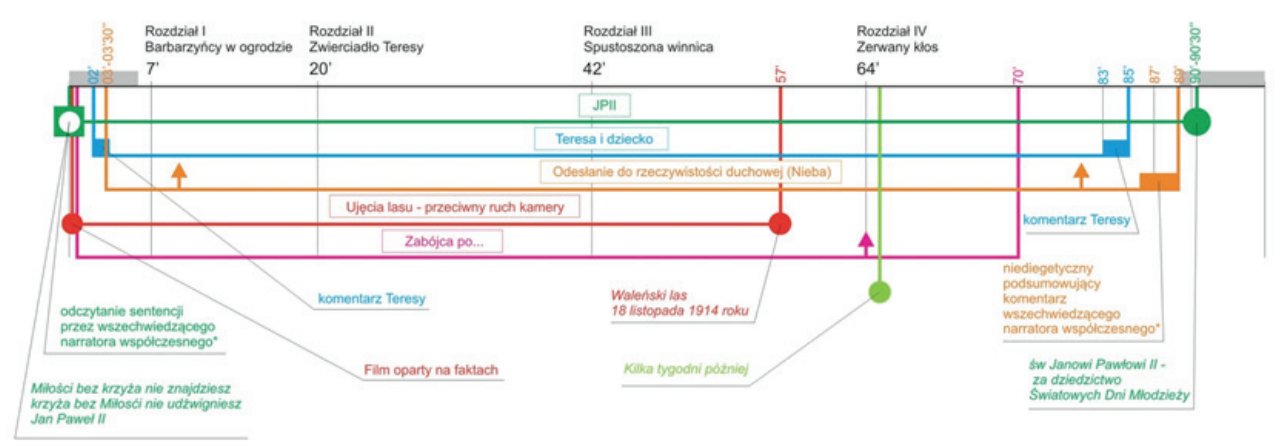

Ryc. 5

Pozostałe dwie klamry maja odmienny charakter, obydwie zostały otwarte w czołówce. Pierwsza z nich - przedstawiająca miotającego się w lesie po śmierci bohaterki rosyjskiego żołnierza - zamknięta jest już w 70. minucie filmu. Druga (jeszcze wcześniej zakończona - w 57. minucie) ma charakter zapowiedzi tragicznych wydarzenia. Przedstawia (filmowany z poziomu koron drzew) las (domyślnie okolice śmierci bohaterki), w tle rozbrzmiewa spokojna muzyka, w obydwu kadrach pojawiają się napisy. W pierwszym jest to: „Film oparty na faktach”, natomiast w drugim: „Waloński las. 18 listopada 1914 roku”. Napisy wskazują na bardzo konkretną rzeczywistość - po pierwsze potwierdzają prawdziwość opowieści, po drugie dookreślają czas i miejsce wydarzeń. W ujęciu otwierającym kamera 
przemieszcza się w prawo, natomiast w zamykającym - z tą samą prędkością w lewo. Ten ruch, zawartość kadrów (łącznie z elementem informacyjnym) i ich charakterystyka wyraźnie parują te ujęcia. Należy tu także zauważyć, że jedyny pozaklamrowy napis pojawiający się w filmie zlokalizowany jest na początku rozdziału czwartego („Kilka tygodni później”) i poprzedza odczytanie przez księdza listu omawiającego rany zadane Karolinie Kózkównie (ryc. 6 i 7).

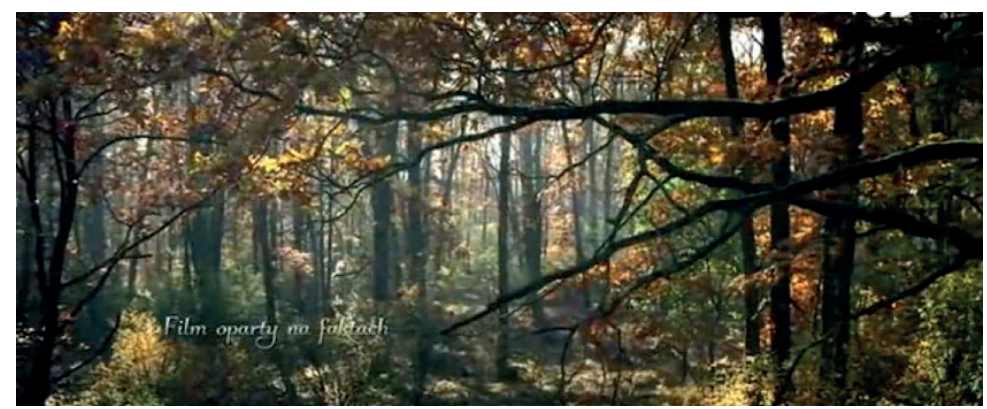

Ryc. 6

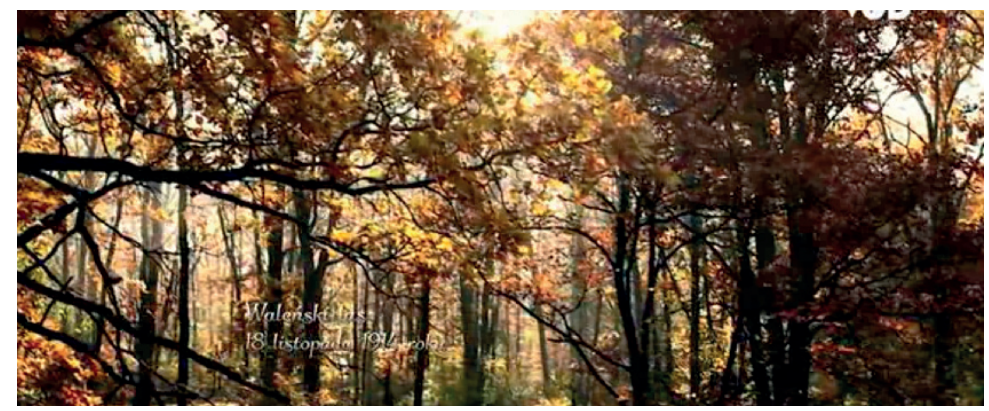

Ryc. 7

Opisane klamry kompozycyjne nie mają jednakowej struktury, nie wszystkie dotyczą tego samego zabiegu kompozycyjnego, jednak podczas odbioru filmu są one wyraźnie widoczne, wiążą się z konstrukcją całego obrazu filmowego i każda z nich ma swój początek przed lub w czołówce filmu (większość ich otwarć sąsiaduje ze sobą w kolejnych ujęciach).

\section{RETROSPEKCJE}

Kolejnym elementem poddanym analizie są pojawiające się w filmie retrospekcje. Podobnie jak stosowanie innych związanych z możliwościami materii filmowej narzędzi konstrukcyjnych, ich wprowadzanie do filmu może pomagać widzowi 


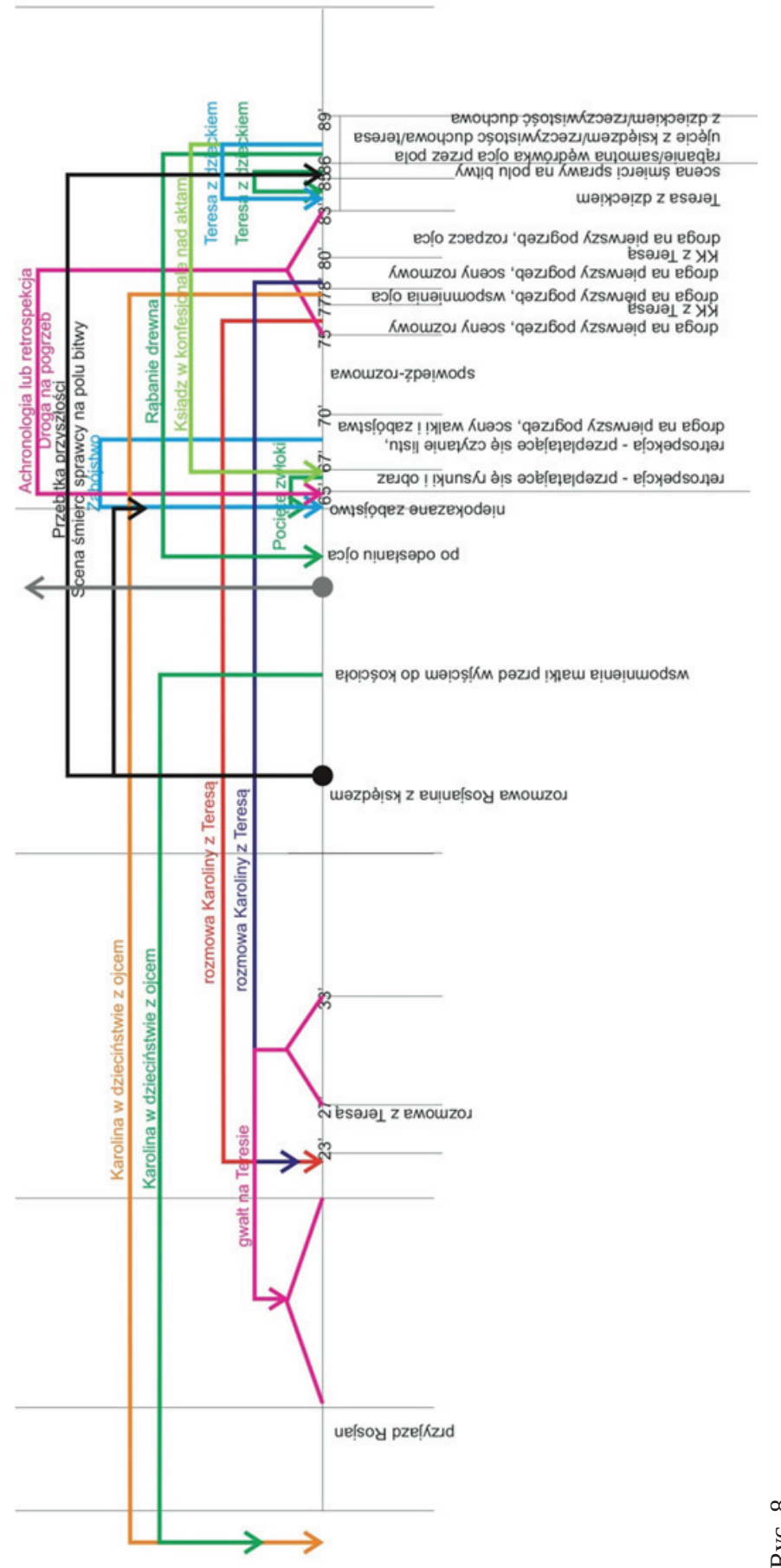


w narracyjnym odtwarzaniu fabuły. Jednak w tym przypadku, przede wszystkim za sprawą ich liczebności oraz sposobu i miejsca zastosowania w filmie, wpisują się raczej w jakiś rodzaj narzucającej się strategii dezinformującej. Przeprowadzona próba ich identyfikującej rekonstrukcji napotkała szczególne problemy w drugiej połowie czwartego rozdziału. Niewątpliwie ta część filmu jest najtrudniejsza analitycznie, przede wszystkim ze względu na znaczne nagromadzenie krótkich i różnorodnych konstrukcyjnie ujęć. Można by nawet zaryzykować stwierdzenie o chaosie pojawiającym się w tej części sjużetu i repetycji ujęć i scen, które z punktu widzenia fabuły jedynie powtarzają (być może celowo, aby dodatkowo podbić znaczenie) treści już przekazane (ryc. 8).

W filmie udało się zidentyfikować czternaście odesłań do rzeczywistości w innym czasie, z czego dwa odnoszą się do przyszłych, a nie przeszłych wydarzeń, a dwa inne odwołują się do przeszłości niepokazanej w filmie. Pozostałe odsyłają odbiorcę do wprowadzanych wcześniej scen. W sumie odnoszą się do co najmniej dziewięciu wydarzeń. Większość nie jest pokazywana w sposób ciągły, lecz poprzez liczne pojedyncze przeskoki i obrazowo-czasowe migotanie rzeczywistości ekranowej, naprzemiennie zmontowane $\mathrm{z}$ aktualnym czasem wewnątrzkadrowym. W tym wyliczeniu pominięte zostały te elementy, które należały do klamer kompozycyjnych.

\section{RELACJA DO RZECZYWISTOŚCI 1 - CZAS}

Czas fabuły sugerowany sjużetem obejmuje kilka miesięcy - począwszy od późnego lata aż do późnej jesieni (lub nawet wczesnej zimy). Widoczne jest to przede wszystkim w wyraźnie eksponowanej przyrodzie, strojach, pracach polowych. Także w materiałach prasowych producenta mówi się o tym, że historia wydarzyła się latem i jesienią. W tych samych materiałach pojawia się zapewnienie „o bardzo rzetelnej i dokumentalnej relacji z życia bł. Karoliny” (Materiały, 2017, s. 5). W rzeczywistości prawdziwe i dokładnie udokumentowane przez im współczesnych wydarzenia miały miejsce pomiędzy 14 a 18 listopada (początek wyznacza data przybycie rosyjskiego oddziału w okolice Wał-Rudy, a koniec zabójstwo). Pojedyncze sceny ukazują pogrzeb Karoliny Kózkówny, który miał miejsce 6 grudnia. Zatem cała przedstawiona historia w rzeczywistości nie trwała kilka miesięcy, ale co najwyżej 3 tygodnie.

Taka zmiana została wprowadzona najprawdopodobniej ze względu na drugi - poza męczeńską śmiercią bohaterki - wątek, czyli historię Teresy, wpisujący się w ochronę życia poczętego bez względu na okoliczności. Posługując się rzeczy- 
wistym wymiarem upływającego czasu i nakładając go na wydarzenia ukazane w filmie, dochodzi do treściowych i wizualnych paradoksów. W filmie pokazane są wykopki ziemniaków, które najpóźniej można przeprowadzić na początku października (a lepiej we wrześniu), do listopada nikt nie pozostawia na łąkach kop niezebranego siana, las w połowie listopada nie jest już typowym reprezentantem złotej polskiej jesieni. Podtrzymując zabieg nakładania czasu rzeczywistego na filmową opowieść, większy problem wiąże się jednak z ukazywaniem Teresy i stopnia zaawansowania jej ciąży. W drugim dniu po gwałcie wygląda ona jak w co najmniej czwartym miesiącu ciąży, natomiast w osiemnastym dniu (przy okazji pogrzebu) - jak na dwa miesiące przed rozwiązaniem (ryc. 9 i 10). W tym przypadku, nawet odrzucając wierne i rzetelne odwzorowywanie krótkiego czasu prawdziwych wydarzeń, trudno jest zaakceptować tę wizualizację, przyporządkowując ją do sugerowanych w producenckich i realizacyjnych założeniach akcji filmu dziejącej się na w czasie czterech miesięcy - od września do grudnia.

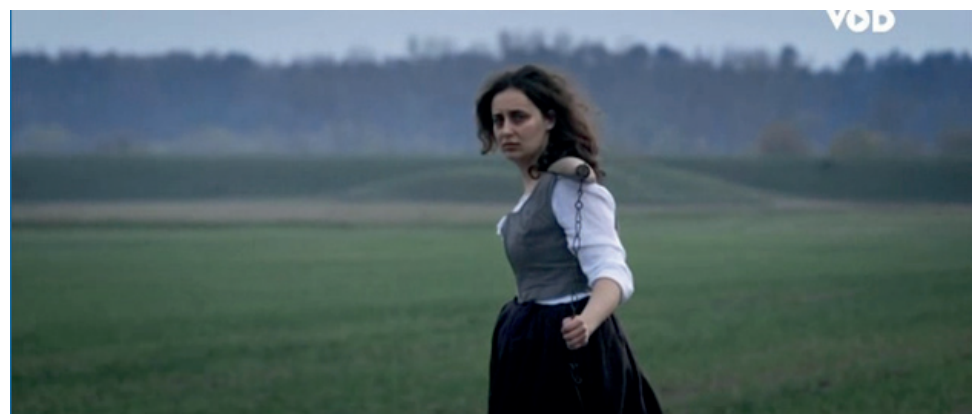

Ryc. 9

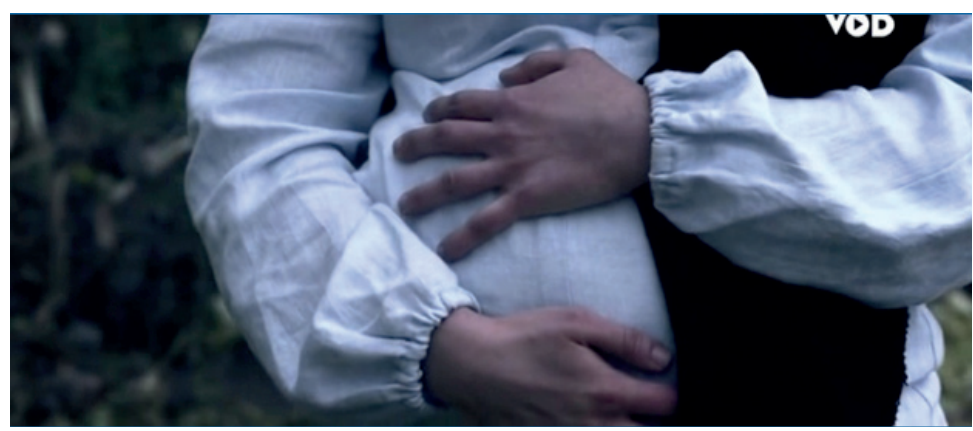

Ryc. 10

Bardzo trudno jest na płaszczyźnie narracyjnej - poza jedną konkretną identyfikacją wprowadzoną wspomnianym już ujęciem zawierającym konkretną datę (18 listopada 2014 roku) - określić upływ czasu. Nie sugerują go jednoznacznie 
ani poszczególne sceny, obrazowanie, ani też wydarzenia, podporządkowując się w pełni tezom (i tematom społecznym), jakie zostały zawarte w tym filmie. Nie ułatwiają tego także ani liczne klamry kompozycyjne, ani retrospekcje, ani też achronologiczna konstrukcja poszczególnych części filmu (w szczególności czwartego rozdziału).

\section{RELACJA DO RZECZYWISTOŚCI 2 - ROSJANIE}

Jednym z najbardziej interesujących elementów świata przedstawionego są sprawcy nieszczęścia i śmierci głównej bohaterki - rosyjscy żołnierze. Ukazani są zgodnie ze schematem, któremu nie oparłby się chyba żaden twórca pracujący nad takim obrazem. Są pewni siebie, prostaccy, głośni, po wojskowemu twardzi, za nic mają miejscową ludność polską, chcą kobiet i zabawy. Jednym słowem - niemalże idealnie, a na pewno całkowicie jednoznacznie reprezentują barbarzyńców przychodzących jak zawsze ze wschodu.

We wszystkich relacjach z tragicznych wydarzeń, jakie miały miejsce w podtarnowskiej wsi, powtarza się informacja o Rosjanach wchodzących w skład oddziału, w którym znajdował się także sprawca zabicia Karoliny Kózkówny. Nigdzie nie pojawia się najmniejsza nawet sugestia, że jest to inna narodowość lub że można w inny sposób zidentyfikować ich pochodzenie (Jaklewicz, 2003). Dlatego też bardzo dziwne jest, że rozmawiają oni ze sobą w języku ukraińskim. Poszukując najprostszych wyjaśnień tej kwestii, można by podejrzewać, że doszło do pomyłki w zlecaniu tłumaczenia. Jednak w tyłówce filmu wymieniona jest osoba odpowiedzialna za „tłumaczenie dialogów ukraińskich”.

Sięgając dodatkowo do przyjętego założenia o odpowiedzialnym za kształt dzieła twórcy, należy zatem przyjąć, że zabieg zamiany języka rosyjskiego na język ukraiński był w pełni celowy. Można by próbować znajdywać jeszcze inne uzasadnienia tego zabiegu, jak choćby to, że tłumaczenie na ukraiński było tańsze albo w ogóle bezpłatne. Jednak chyba o wiele łatwiej jest znaleźć osobę znającą język rosyjski niż ukraiński, przynajmniej na takim poziomie, jaki jest reprezentowany w dialogach pomiędzy rosyjskimi żołnierzami. Nawet korzystając z automatycznych translatorów, istniałaby szansa jakiejkolwiek korekty tłumaczenia i wymowy, ponieważ jeszcze nie wymarło pokolenie, które przez lata musiało uczyć się tego języka w ramach socjalistycznego systemu edukacji. Do tej grupy prawdopodobnie należy także aktor grający rolę mordercy głównej bohaterki. Dzięki temu miałby on szansę mówić po rosyjsku o wiele lepiej niż mówił po ukraińsku. Zresztą obydwaj rosyjscy oficerowie mówiący w tym języku sprawiają wrażanie, jakby 
wypowiadanie słów sprawiało im ból. Jakby tego było mało film jest całkowicie niegramatyczny, wymieszany z językiem polskim, z nieprawidłowym akcentowaniem (w języku ukraińskim może to wpływać na rozumienie wypowiedzi) i licznymi błędami leksykalnymi i stylistycznymi. Nie jest to także żadna z odmian (nie tyko odrosyjskich) surżyków, często występujących na Ukrainie.

W ramach interpretacji trzeba brać pod uwagę możliwość, że celowe zastąpienia jednego języka innym, miało u odbiorców wywołać efekt automatycznego skojarzenia i utożsamienie ogólnego brzmienia języka ukraińskiego ze sprawcami zabicia Karoliny Kózkówny. Teza ta wiąże się z jedną z zasad dotyczących badania dyskursu, która wskazuje, że w dyskursie medialnym odzwierciedla się system wartości reprezentowany przez nadawców przekazu (van Dijk 1993). W tym przypadku dotyczy to wpisania się tezy o złych Rosjanach (brzmiących jak Ukraińcy) w ogólny dyskurs mediów Tadeusza Rydzyka. Tematy polskich kresów, Wołynia i prześladowań Polaków przez Ukraińców często się w nich pojawiają. Także coraz liczniejsze przybywanie ich do Polski i osiedlanie się nie jest traktowane przez tę grupę mediów jako zjawisko pozytywne. W oparciu o takie podejście do Ukraińców oraz biorąc pod uwagę podporządkowanie treści filmu także aktualnym kwestiom społecznym, można postawić tezę, że chodziło o pośrednie obciążenie Ukraińców winą za śmierć bohaterki. Obciążenie pośrednie, ponieważ w dalszym ciągu żołnierze są identyfikowani jako Rosjanie, jednak język, którym się posługują, jest podobny do tego języka, który jest coraz częściej słyszany w Polsce wraz z przybywającymi z Ukrainy osobami.

\section{FILMOWE GRZECHY NADMIARU 1 - IDEOLOGIA}

Płażewski (1961), powołując się na Karola Irzykowskiego, pisał o znaczeniu gustu i wyrobienia widza dla sztuki kinematograficznej. To odbiorca, wstępując na coraz wyższe poziomy percepcji obrazu filmowego, miał wymuszać na twórcach kina - przez swoje zaawansowane oczekiwania - coraz to doskonalsze konstruowanie filmów i co za tym idzie - rozwój sztuki filmowej. Jednak rzeczywistość kinematograficzna została zdominowana przez dwa demony, które widoczne i aktywne były od początku istnienia filmu. Pierwszym z nich jest dominujący homo ludens, który nie stoi na przeszkodzie rozwoju kinematografii, choć ją w znacznym stopniu spowalnia i kanalizuje w kierunku, który ma zaspokoić niewygórowane oczekiwania widza. Ten demon wzmacnia znaczenie sztuki filmowej i umożliwia powolną jej ewolucję, choć kierunek, jaki jej wyznacza, wiąże się raczej z eisensteinowskimi pomysłami na petardy umieszczane pod fotelem kinowym niż z jego 
koncepcjami rozwoju montażu. Drugi demon jest straszniejszy, gdyż korzysta z jak najprostszych i zarazem najskuteczniejszych technik przekazu filmowego, sięga do podstawowych instynktów i czyni z filmu narzędzie sterowania świadomością zbiorową i myślą społeczną - także zgodnie z koncepcją Eisensteina odnoszącymi się do porwania i zaangażowania widza (Bocheńska, 1995). Tym demonem jest ideologia.

Biorąc pod uwagę typ duchowości błogosławionej Karoliny Kózkówny, wiąże się on przede wszystkim z oddaniem się Bogu, zawierzeniem mu i czystością (Jaklewicz, 2003). Bez większych problemów można by zrealizować hagiograficzny obraz, który koncentrowałby się na wiernym przedstawieniu części życia tej postaci oraz jej śmierci i związanymi z tym okolicznościami i konsekwencjami. Pomimo tego twórcy filmu zdecydowali się - wiernie zachowując wiele precyzyjnie zidentyfikowanych i przedstawionych w filmie elementów z życia bohaterki (dotyczy to zarówno takich detali, jak obrazy wiszący w domu, jak i istotniejszych elementów - np. opisy ran zabitej męczennicy został sformułowany w oparciu o źródłowe dokumenty watykańskie z procesu beatyfikacyjnego) - na kreacyjne i także ideologiczne poszerzenie filmu o bardzo rozbudowaną historię Teresy. Sposób opowiedzenia tego wątku i miejsce, jakie zajmuje w sjużecie, wykracza poza proste i zgodne z konwencją opisu żywotów świętych ukazanie, jak dobra i oddana Bogu była główna bohaterka, wpływając także na swoje otoczenie. Nie jest to jedynie uzupełnienie potrzebne do tego, aby wzmocnić doskonałość postaci głównej. W całości wykreowana historia zgwałconej dziewczyny i jej losy nie tylko modyfikują (być może trwale) identyfikację typu duchowości Karoliny Kózkówny, wiążąc ją z obroną życia poczętego - także tego powstałego w wyniku gwałtu - ale i wpisują się w nieustający, choć zmiany pod względem swojej intensywności, konflikt pomiędzy zwolennikami całkowitego zakazu aborcji a zwolennikami istniejącego w Polsce - niezadawalającego żadnej ze stron kompromisu aborcyjnego oraz tymi, dla których jakiekolwiek ograniczenie w tym zakresie wydaje się nieakceptowalne. Biorąc pod uwagę lata, w jakich film ten powstał i wywoływał bezpośrednie skutki społeczne (2015-2017), można w sposób w pełni uzasadniony stwierdzić, że wątek Teresy wpisał ten film w społeczną sferę intensywnego publicznego dyskursu dotyczącego aborcji. W tych bowiem latach władzę w Polsce objęły ugrupowania sprzyjające koncepcjom intensyfikowania w życiu społeczny katolickiej duchowości, starając się spełnić przynajmniej część postulatów polskiego Kościoła rzymskokatolickiego. Skutkowało to zarówno licznymi wypowiedziami polityków oraz osób duchownych, jak i parlamentarnymi debatami nad zaostrzeniem zasad w tym zakresie oraz skierowaniem jesienią 2017 roku do Trybunału Konstytucyjnego wniosku o sprawdzenie, czy przesłanka 
dotycząca wad i nieuleczalnych chorób płodu zezwalająca na legalną aborcję jest zgodna z Konstytucją RP.

\section{FILMOWE GRZECHY NADMIARU 2 - STYLISTYKA}

Stylistyka i konstrukcja filmu decydują o spójności dzieła filmowego i wpływają na jego odbiór. W nieeksperymentalnym kinie fabularnym są także (niejedynym) wyznacznikiem przypisania gatunkowego, a dążenie do jak najbardziej nienarzucających się rozwiązań formalnych (Przylipiak, 1994), ułatwiających odbiorcy sprawne scalenie składników filmu i rekonstrukcję spójnej fabuły, decydując także o jego ocenie obrazu i stopniu zaangażowani w rzeczywistość ekranową świata przedstawionego. Gatunkowe kino religijne, w swojej charakterystyce zawsze będące kinem zawierające konkretną ideę (Kempna-Pieniążek, 2013), może sobie pozwolić na nieznaczne przerysowanie niektórych elementów konstrukcyjnych filmu, jednak można czynić to w ograniczonych ramach nienaruszających możliwości efektywnej percepcji obrazu filmowego.

W przypadku Zerwanego kłosa pojawia się problem interpretacyjny związany z formalnymi aspektami konstrukcji obrazu. Najbardziej problematyczny pod tym względem jest czwarty rozdział, który sprawia wrażenie blisko półgodzinnego podsumowania i zakończenia filmu. W pojawiających się ze szczególną intensywnością w tej części mnogości retrospekcji, pojedynczych ujęć oderwanych treściowo i stylistycznie od sąsiednich kadrów, ich achronologicznym montażu, trudno jest dostrzec jakąkolwiek spajającą je koncepcję, którą można uzasadnić formalnymi zasadami związanymi z wykorzystaniem języka filmu. Taki kompilacyjny montaż, w którym ze względu na muzykę oraz głos narratora ujęcia stają się jedynie dodatkiem do warstwy dźwiękowej sprawia, że z niemalże całego czwartego rozdziału filmu tworzy część symboliczno-impresyjną.

Jednak problem organizacji formy filmowej dotyczy całego filmu, który sprawia wrażenie kina warsztatowego, mającego za zadanie wykorzystać jak największą ilość rozwiązań stylistycznych wynikających z dostępnych możliwości technicznych oraz szkolnego katalogu sposobów ich wykorzystania. Szczególnie zauważalne przez swoją nieuzasadnialność są wśród nich: nadużywanie długiej ogniskowej obiektywu, związane z tym częste wąskie kadrowanie (skutkujące ciągłą sugestią skupienia widza na niepokazanych jednak przez grę aktorską emocjach bohaterów) i znaczna liczba ujęć zwolnionych. Całkowicie pozbawione fabularnego i formalnego uzasadnienia (ani nie buduje ono nastroju, ani nie konstruuje złożonych sensów (Adamczak, 2010)) jest wykorzystujące perspektywę sferyczną 
ujęcie z drona. Każde z powyższych rozwiązań ma swoją - określoną percepcją widza - funkcję i w celu zachowania spójności i percepcyjnej akceptowalności odbiorczej może być celowo wykorzystywane. Ich nadmiar i nieuzasadnione stosowanie wprowadzają błędne tropy interpretacyjne, które mogą być zatuszowane (choć w dalszym ciągu nieuzasadnione) jedynie na płaszczyźnie emocjonalnego przekazu treści.

Narzucający się w odbiorze ciągły i nadmiarowy ruch kamery wprowadza wrażenie niepokoju. O ile może on być elementem dobrze podkreślającym budowanie nastroju, o tyle stosowanie go w większości scen, bez wyraźnego uzasadnienia i stosowania jakichkolwiek reguł semantycznych wiążących strukturę filmu i zabiegi formalne z treścią, w rzeczywistości nie służy niczemu i wywołuje wrażenie ciągłej pogoni. Gdyby zastosować ten element jako intensyfikujący się wraz z upływem czasu (wprowadzany stopniowo lub w związku z konkretnymi ujęciami) składnik budowania nastroju i nadciągającego niebezpieczeństwa, byłoby to ze wszech miar słuszne. Jednak nadpobudliwa ruchowo kamera dominuje także w części podsumowująco-refleksyjnej filmu, w której takie elementy, jak: spokój, cisza i nieruchome kadry najlepiej konstruowałyby znaczenia.

Przy wynikających z powyższych rozwiązań technicznych problemach z rekonstrukcją fabuły słabo dostrzegalna jest jedna z niewątpliwych zalet tego filmu. Należy bowiem docenić drobiazgowość rekonstrukcyjną na poziomie szczegółu, widoczną przede wszystkim w urządzeniu wnętrza domu, w którym mieszka bohaterka, relacjach z rodziną i codziennych (głównie religijnych) zachowaniach, które zostały zrekonstruowane w filmie. Jednak ginie ona w natłoku fikcyjnych wątków, odrealnionej konstrukcji czasu i natłoku nieuzasadnionych rozwiązań technicznych. Nawet bez tych utrudnień ich rozpoznanie wymaga szczegółowej wiedzy na temat życia Karoliny Kózkówny, a przy ich nagromadzeniu, do tego, aby docenić wierność zachowaną w szczególe, potrzebny jest także zmysł filmowej obserwacji i szczególna percepcja odbiorcza, wykraczająca poza uśredniony przez swą powszechność jej poziom. Wiedza ta jest także konieczna do tego, aby zrozumieć wszystkie elementy świata przedstawionego i aby móc zrekonstruować zgodność z faktycznymi wydarzeniami. Część z nich jest bowiem bez tej wiedzy niejasna lub mało rzeczywista, czy też po prostu mało prawdopodobna. Przede wszystkim (choć nie wyłącznie) dotyczy to końcowej części filmu, i elementów wyraźnie wyodrębnionych przez umieszczenie ich w rozdziale czwartym - Zerwany kłos (nawet w kinie tytuł żadnej części nie powinien być tożsamy z tytułem całości, ponieważ pojawia się wówczas pytani o sens wprowadzania pozostałych części). 


\section{NIEAKSJOLOGICZNA WARTOŚĆ}

Odwołując się do oceny filmu przez widzów, ze względu na wskazane na początku tej analizy uwarunkowania, niewymierne byłoby oparcie się na komentarzach i opiniach, jakie pojawiały się po jego premierze w mediach. Sięgając jednak do jedynie bezkomentarzowego (w skali od 1 do10) zakresu oceny i najbardziej znanego polskojęzycznego filmowego portalu Filmweb, przypisana została mu ocena 4,9, czyli niewiele mniej niż Dwóm koronom z 2017 roku o życiu Maksymiliana Marii Kolbego oraz Bogu w Krakowie z 2016 roku przywołującym postać św. Alberta Chmielowskiego. Znacznie gorzej zostały ocenione filmy Smoleńsk oraz Botoks.

Zgodnie z informacjami pochodzącymi z Polskiego Instytutu Sztuki Filmowej (2017) pod względem liczby widzów, która obejrzała ten film (do lipca 2018 roku), znalazł się on na piętnastym z trzydziestu dziewięciu polskich premier filmowych z 2017 roku, przy zaledwie 89 kopiach wyprzedając kilkanaście filmów dystrybuowanych w dwukrotnie większej liczbie kopii i osiągając ogólne audytorium 210226 widzów. Po premierze (luty 2017) nie trafił do dziesiątki najlepszych weekendowych projekcji, jednak zabrakło mu do tego naprawdę niewiele, bo zaledwie 1029 widzów (osiągnął wtedy wynik 24305 sprzedanych biletów (Spór, 2017).

Ten niewątpliwy sukces wiąże się z oczywistą wartością tego filmu dla środowiska związanego z mediami Tadeusza Rydzyka. Przede wszystkim właśnie to środowisko było głównym odbiorcą tego filmu i jego ocena jest decydująca. W przypadku tej grupy (Bobrowska, 2014; Migas, 2005; Mielczarek, 2009) o wiele ważniejsze niż kwestie jakości konstrukcji filmu i sposobu organizacji stylistyki filmowej są zagadnienia treściowe, emocje i samo to, kto jest producentem tego obrazu. Dominująca pozytywna opinia o filmie w tym środowisku wiąże się ściśle z jego tematyką i głównymi wątkami, wpisującymi się w retorykę wartości reprezentowanych przez tę grupę i współdzielonych z mediami Lux Veritatis. Są to w pewnym uproszczeniu - nieugięta niewinność i zaufanie Bogu w przypadku wątku Karoliny Kózkówny oraz ochrona życia poczętego ponad wszelkie koszty w przypadku całkowicie fikcyjnego wątku Teresy.

Nie bez znaczenia dla ilościowego sukcesu pozostaje promocja filmu, która była realizowana w 2017 roku przede wszystkim za pośrednictwem Radia Maryja. W tym czasie wyemitowano blisko 40 odrębnych audycji - wszystkie pozytywnie oceniające film (niestety także pod względem wartości sztuki filmowej). Specyfika filmu religijnego i związek tego tytułu z mediami Tadeusza Rydzyka sprawiają, że wiążą się z nim także dwa inne zjawiska. Pierwszym były organizowane przez parafie, szkoły, biblioteki i członków Rodziny Rada Maryja grupowe wyjazdy 
(dla osób niemogących obejrzeć filmu w swoich miejscowościach) na projekcje tego filmu (liczba wyników wyszukiwania w Google frazy „wyjazd zerwany kłos” pokazuje niebagatelną skalę tego zjawiska). Drugim natomiast jest pozakinowe dystrybucyjne życie tego filmu. Filmy religijne (poza dystrybucją na różnych nośnikach i dostępem on-line) są często pokazywane podczas uroczystości i zjazdów religijnych, a także na lekcjach religii i spotkaniach formacyjnych, właściwie nigdy nie odchodząc do archiwum. Tego mechanizmu - pod względem wciąż wzrastającej liczby widzów - może pozazdrościć niemalże każdy inny film.

\section{POSUMOWANIE}

Odbiorcą omawianego filmu jest konkretny widz oczekujący opowieści o męczeńskiej śmierci pobożnej dziewczyny, ginącej w obronie swego dziewictwa. Dodatkowo odbiorca otrzymuje także historię, która wpisuje się w szerszy dyskurs (zgodny z jego światopoglądem) wykraczający zarówno poza ramy oryginalnej historii, jak i samego filmu - historię Teresy - co wiąże się z obroną każdego życia poczętego, odnosząc się tym samym do aktualnego dyskursu społecznego.

Film ten, jak na opowieść alegoryczną, jest zbyt mocno osadzony w rzeczywistości, natomiast jak na film w pełni realistyczny i biograficzny, ma zbyt wiele elementów kreacyjnych i nierealistycznych. W całości nie tyle przekazuje informacje i prawdę, nie tyle odsyła nas w pełni do świata rzeczywistości duchowej, ale i udowadnia określoną tezę lub też nawet dwie tezy. Koncentruje się na wartości i zwycięstwie życia pod postacią narodzonego dziecka, co jest wytłumaczalne i jasne jedynie w retoryce i stylistyce religijnej oraz takiej konwencji odbiorczej (Polska, 2017). Wyłącznie w ramach takiej ramy interpretacyjnej akceptowalny jest także składnik drugiej tezy mówiącej o tym, że śmierć jest lepsza, niż pohańbienie.

Filmowym grzechem głównym i chyba jedynym twórców Zerwanego kłosa jest nadmiar. Jednak nadmiarowość nie dotyczy tylko i wyłącznie sprzętowych udogodnień, z których „aż żal byłoby nie skorzystać skoro wiemy jak”, co skutkowało między innymi ujęciem z drona, niemalże nieustannie poruszającą się stabilnie kamerą i wykorzystaniem szerokiej gamy obiektywów. Brak umiaru widoczny jest także w szkolnym podejściem do możliwości tworzywa filmowego. Szczęśliwie nie wszystkie jego składniki zostały wykorzystane. Jednak wystarczające są: pięć sprzecznych ze sobą klamr niezsynchronizowanych z podziałem na rozdziały, napisy w kadrach jeszcze bardziej burzące wprowadzony przez nie porządek, różnorodnego rodzaju i typu komentarz narratorskie, nadużywanie wąskiego kadrowania, wciskająca się, komentująca i narzucająca nastrój i interpretację muzyka, 
nie piętrowe, ale bardzo liczne retrospekcje i odesłania wewnątrzfilmowe, bardzo duża liczba ujęć zwolnionych, umistycznienie upływu czasu i jego osadzonej w przyrodzie identyfikacji. W efekcie powstał obraz duszny i barokowo, choć jednocześnie surowo przeładowany, pozbawiony rytmu i logiki konstrukcyjnej, ukierunkowany na skuteczny (co się udało) przekaz tez, trudny w odbiorze nieopierającym się na przeżyciu religijnym i formalnie zły.

W hagiologiach z założenia elementy kulturowe i religijne były bardziej istotne niż prawda historyczna. W tym przypadku należy to rozciągnąć także na sposób wykorzystania stylistyki filmowej. Dlatego o wartości tego obrazu decyduje jego aspekt gatunkowy, który wiąże się ze spełnieniem przez niego celu społecznego. Nie zmienia to jednak tego, że wartość tego obrazu z punktu widzenia estetyki, stylistyki, wykorzystania języka filmu jest co najwyżej warsztatowa. Twórcom zabrakło pokory, skromności i ubóstwa.

Jednak w filmie jest jedna scena, które zachowuje te cechy. To pierwsze ujęcie czwartego rozdziału, płynnie (jako jedyne) przechodzące do spokojnego ruchu kamery od kadru (obrazka) wprowadzającego. Taka nienadmiarowa i nienerwowa stylistyka zastosowana do całości uratowałaby ten film pod względem jakości sztuki filmowej. Naprawdę szkoda, że w całości nie został właśnie tak stworzony, dodatkowo nie z jedynie deklarowaną wiernością faktom, które w swym tragizmie nie potrzebują kreacyjnych uzupełnień i dodatkowych ideologicznych tez.

\section{Bibliografia}

Adamczak, M. (2010). Globalne Hollywood, filmowa Europa i polskie kino po 1989 roku: przeobrażenia kultury audiowizualnej przełomu stuleci. Gdańsk: Wydawnictwo słowo/ obraz terytoria.

Bobrowska, E. (2014). Struktury znaczeniowe w hasłach na transparentach, obrońców Radia Maryja i Telewizji Trwam. Zeszyty prasoznawcze, 3 (219), s. 456-471.

Bocheńska, J. (1995). „Nieobojętna sztuka” i nieobojętny widz. Polska Sztuka Ludowa. Konteksty, t. 49 z. 2, s. 76-77.

Bordwell, D. (1985). Narration in the Fiction Film. Madison: Univ. of Wisconsin Press. Jaklewicz, T. Patronka molestowanych - bł. Karolina Kózkówna. Pobrane z: https://kosciol. wiara.pl/doc/490408.Bl-Karolina-Kozkowna-Patronka-molestowanych.

Kempna-Pieniążek, M. (2013). Formuły duchowości w kinie najnowszym. Katowice: Wydawnictwo Uniwersytetu Śląskiego.

Materiały dla dziennikarzy (2017). Pobrane z: http://www.zerwanyklos.pl/files/Materiały o filmie.pdf.

Mielczarek, T. (2009) Od medialnego koncernu do partii politycznej. Rocznik Prasoznawczy, 3, s. 41-57. 
Migas, P. (2005). Konglomerat medialny Radia Maryja. Zeszyty prasoznawcze, 1-2 (181-182), s. 33-50.

Płażewski, J. (1961). Język filmu. Warszawa: Wydawnictwo Artystyczne i Filmowe.

Polska: Zerwany kłos o najważniejszych wartościach. (2017). Pobrane z: http://www. it.tarnow.pl/index.php/Atrakcje/Aktualnosci/Polska-Zerwany-klos-o-najwazniejszychwartosciach.

Polski Instytutu Sztuki Filmowej. (2017). Premiery 2017 (stan na 5 lipca 2018). Pobrane z: https://www.pisf.pl/rynek-filmowy/box-office/table:polskie-premiery-2017.

Przylipiak, M. (1994). Kino stylu zerowego: z zagadnień estetyki filmu fabularnego. Gdańsk: Gdańskie Wydawnictwo Psychologiczne.

Salwowski, M. (2017). Zerwany kłos. Pobrane z: http://kulturadobra.pl/zerwany-klos.

Spór, K. (2017). Widownia w polskich kinach dopisuje. Pobrane z: http://sporwkinie. blogspot.com/2017/02/widownia-w-polskich-kinach-dopisuje.html.

Tatarska, A. (2017). „Zerwany kłos”. Świadectwo... złego smaku [RECENZJA]. Pobrane z: http://cojestgrane24.wyborcza.pl/cjg24/1,13,21379859,148674,-Zerwany-klos--Swiadectwo---zlego-smaku--RECENZJA.html.

Thompson, K., Bordwell, D. (1976). Space and Narrative in the Films of Ozu. Screen, 17 (2), s. 41-73.

Van Dijk, T.A. (1993). Principles of Critical Discourse Analysis. Discourse \& Society, 4 (2), s. 249-283.

Van Dijk, T.A. (red.). (1997). Discourse as Structure and Process: Discourse Studies: A Multidisciplinary Introduction. Londyn: Sage. 